\title{
Need for Promotion of Agriprenuership to Address the Challenges in Indian Agriculture: A Critical Review
}

\author{
C. Padma Veni* and K. Bhagya Lakshmi
}

Faculty, Extension Education Institute, Rajendranagar, Hyderabad, Telangana, India

*Corresponding author

\section{A B S T R A C T}

\begin{tabular}{|c|}
\hline Keywords \\
\hline $\begin{array}{l}\text { Promotion of } \\
\text { Agriprenuership, } \\
\text { Agriculture }\end{array}$ \\
\hline Article Info \\
\hline $\begin{array}{l}\text { Accepted: } \\
18 \text { September } 2018 \\
\text { Available Online: } \\
10 \text { October } 2018\end{array}$ \\
\hline
\end{tabular}

Agriculture and allied sectors provide livelihoods for the vast majority of the rural population in India. Agriculture is still perceived as a way of life rather than an enterprise in our country. But agriculture and its allied sectors are going through a phase of transition all over the world. In this changing scenario, Indian agriculture has to take a new shape by expanding its scope beyond the limits of mere primary agriculture. A paradigm shift from agriculture to agriprenuership is indispensable to revitalize Indian agriculture. In this context, promotion of agriprenuership through facilitating farmers and transforming them as agriprenuers is need of the hour. In this context, an attempt has been made to analyze the scope and challenge for agriprenuership in India. This paper thoroughly examines the major challenges for Indian agriculture and need for promotion of agriprenuership promotion.

\section{Introduction}

Agriculture all over the world is going through a phase of transaction.

In this changing scenario, agriculture need to take new shape by expanding its activities like diversification, value addition, precision farming, high tech agriculture, export marketing, organic farming to make it more viable and profitable enterprise.

But in India, agriculture is considered merely as a family tradition and a livelihood option. Due to changing global trends in agriculture sector, farming should be considered as an enterprise and farmer as an agripreneur.

\section{Changing trends in agriculture}

Subsistence agriculture to Agribusiness

Commodity driven market to Product driven market

Homogenous group of crops to Crop diversification

\section{Farmer to Agriprenuer}

An agripreneur is someone who undertakes a variety of activities in agriculture and its allied sectors with an entrepreneurial spirit (Tripathi and Agarwal 2012). Agriprenuer is a person whose main business is agriculture or agriculture related. (Nagalakshmi and 
Sudhakar, 2012).

\section{Benefits of agriprenuership in Indian context}

Agriprenuership plays various role in growth and development of national economy through entrepreneurship development which increases the income level and employment opportunities in rural as well as urban areas (Bairawa et al., 2014). Promotion of agriprenuership has following benefits in Indian context.

Agripreneurship creates value to primary agriculture and enhances the farm income.

Agripreneurship widens the job opportunities for the people in the rural areas.

Enhanced agripreneurship activity could result in improvement of rural infrastructure which may in turn encourage the growth and development of non-agricultural business activities of the rural economy.

\section{Agriprenuership in India: Scope and potential}

Agriculture sector employs over $52 \%$ of labour force of the country and over $70 \%$ of the Indian rural workforce. The country has second largest country under cultivation and highest area under irrigation (55.8 million hectares). In India, 52\% of total land is cultivable as against $11 \%$ in the world. We have achieved fourfold increase in production of food grains (From 50 million tonnes in 1950 to 230 million tones in2010). All 15 major climates of the world, snow bound Himalayas to hot humid southern peninsula; Thar Desert to heavy rain areas are existing in India. There are 20 agro-climatic regions and nearly 46 out of 60 soil types in the country. Sunshine hours and day length are ideally suited for round the year cultivation of crops.
India is the centre for biodiversity in plants, animals, insects, micro-organism and accounts for $17 \%$ animal, $12 \%$ plants and $10 \%$ fish genetic resources of the globe. In the livestock sector, India has $16 \%$ of cattle, $57 \%$ of buffalo, $17 \%$ of goats and $5 \%$ of sheep population of the world (Mittal, 2009). India is the second largest producer of rice and wheat in the world; first in pulses and fourth in coarse grains. India is also one of the largest producers of cotton, sugar, sugarcane, peanuts, jute, tea and an assortment of spices. The country is now second in production of cereals like Wheat, second in production of vegetables, first in livestock population with $18 \%$ of world's cattle population with and $13 \%$ of world's total milk production is contributed by India. Fifth largest producer of eggs and sixth largest producer of fish with harvesting volumes of 5.2 million tones. We are third in terms of farm mechanization in the world. Above facts and figures indicating the scope and potentials for promotion of agriprenuership in India.

Challenges for Indian Agriculture and Need for promotion of agriprenuership

In spite of the fact that the above favorable conditions are prevailing in India for promotion of agriprenuership, still the Indian agriculture sector is facing variety of challenges as discussed below:

\section{Low Productivity}

Yields of major crops in India are more or less stagnated and that are lower than most of the developing countries. Indian wheat yield stagnated at $28 \mathrm{q} / \mathrm{ha}$ while those of most wheat producing countries was $64 \mathrm{q} / \mathrm{ha}$. Similarly rate of rice production in India is far lower than most of Asian countries (Praveen kumar and M.S. Nain, 2013). The average yield of buffaloes is around 4.0 litres/day, whereas the indigenous cows yield only about $1.0 \mathrm{~kg} / \mathrm{day}$. 
As a majority of the milch animals represent the non-descript, low yielding, the average milk yield of cows in India is only $987 \mathrm{~kg} /$ year per lactation as compared to the world average of $2038 \mathrm{~kg} /$ year.

\section{Shrinking landholding}

The biggest challenge for Indian agriculture is the decreasing size of land holdings, which can potentially make the profession unfeasible. The arable land has shrunk from 0.94 acre per person in 1970 to 0.56 acre per person in 2000 and going by the rate population is increasing it is projected to decrease to 0.56 acre per person by 2025 . Such small holdings create problems in performing farm mechanization operations and make farming non remunerative (Praveen kumar and M.S. Nain, 2013).

\section{Declining interest in agriculture and allied sectors}

In recent years, land based livelihoods of small and marginal farmers are increasingly become unsustainable, since their land has not been able to support family requirements. There are nearly 15 million farmers ('Main' cultivators) fewer than there were in 1991. Over 7.7 million less since 2001, as the latest Census data show. On average, that's about 2,035 farmers losing 'Main Cultivator' status every single day for the last 20 years. And in a time of jobless growth, they've had few places to go beyond the lowest, menial ends of the service sector (The Hindu, May 2, 2013). A survey by National Sample Survey Organization (NSSO, 2005) reveals that $41 \%$ of farmers in India wants to leave agriculture if any other option was available. Even in agriculturally progressive state like Punjab $37 \%$ of the farmers want to leave agriculture. Definitely this percentage might have increased now. Census 2011 also shows that there was a decline in the number of cultivators from 103 millions in 2001 to 95.8 millions in 2011.

\section{Low level of value addition and processing}

India can save up to 25 million tonnes (MT) of food grain, about 10 per cent of its total production, if farmers adopt proper postharvest management practices, according to the latest study by the Associated Chambers of Commerce and Industry of India (Assocham). Due to low processing levels in the country there is a considerable amount of wastage of agricultural and horticultural produce. As per a study conducted by the central Institute of post-harvest engineering and technology, post harvesting losses in 2009 were to the tune of rupees 44,000 crores (Tiwari, 2012). If farmers carry out activities such as postharvest cleaning and grading, around 25 MT food grains can be saved from wastage, said the study titled 'Value addition in agricultural products in India' (October 04, 2013, NDTV profit). Value addition to raw food material in India is only 7 per cent while it is 23,45 and 188 per cent in China, Philippines and UK, respectively (as per National Food Processing Policy, Draft Document, 2000). Studies also reveal that more than four dozen value-added products are produced from derivatives of paddy in a small country like Japan, which produces only 2 per cent of the total world production of paddy. We process less than 2 percent of fruits and vegetables as compared to 30 per cent in Thailand and 80 per cent in Malaysia.

Though India's agricultural production base is reasonably strong, wastage of agricultural produce is sizeable. Processing of fruits and vegetables is a low $2 \%$, around $35 \%$ in milk, $21 \%$ in meat and $6 \%$ in poultry products. By international comparison, these levels are significantly low - processing of agriculture produce is around $40 \%$ in China, $30 \%$ in Thailand, $70 \%$ in Brazil, $78 \%$ in the 
Philippines and $80 \%$ in Malaysia. Value addition to agriculture produce in India is just $20 \%$, wastage is estimated to be valued at around US\$ 13 bn (Rs 580 bn).

\section{Lack of entrepreneurial abilities among farmers}

In general, agripreneurs should be proactive, curious, determined, persistence, visionary, hardworking, honest, integrity with strong management and entrepreneurial skills. Agripreneurship is greatly influenced mainly by the economic situation, education and culture. Singh and Amarendra Pratap (2013) in their study on factors influencing entrepreneurship among farming community in Uttar Pradesh clearly indicated that if the right environment is created and farmers are provided with good infrastructure, technological support, and timely availability of credit it can enhance food production and ensure food security as well as increase in income of the farmers and quality of life

\section{Migration from rural to urban areas}

Migration is the crucial indicator for assess the changing socio-economic conditions at national and international level. It is also a sign of wide disparities in socio-economic and social conditions between the origin and destination. In India migration mostly takes place due to poverty and unemployment.

It is evident from the above table that there is an absolute increase in the urban population The rural urban distribution is $68.84 \%$ and $31.15 \%$. The level of urbanization increased from $27.79 \%$ in 2001 to $31.15 \%$ in 2011 according to Census. The rural population has declined from $72.2 \%$ to $68.84 \%$. The percentage of urban population in India which was only 17 per cent of total population in 1951 is expected to jump to around 42.5 per cent of the total population by 2025 . It is estimated that approximately 2 million people are shifting from rural to urban areas annually and approximately 22 million people have migrated from rural to urban areas since 2001. Agriculture provides principle means of livelihood over 52 per cent of our population which lives in rural India.

Loss of job opportunities in agriculture is primary factor of diving people away from agriculture. Agrarian crisis can gauged from the fact that 240,000 debt ridden farmers committed suicide between 1995 and 2009 (BBC news, Jan 23, 2013). Hence promotion of agriprenuership is the need of the hour to strengthen employment opportunities in the rural areas to sustain agriculture and agro based industries.

To address the above challenges in agriculture sector in India there is an enormous need for promotion of agriprenuership through capacity building, creating infrastructure and providing credit facilities to the farming community.

Table.1 Average yeilds of major crops in India

\begin{tabular}{|c|c|c|}
\hline S. No & Crop & Yeild (q/ha) \\
\hline 1. & Rice & 22 \\
\hline 2. & Wheat & 28 \\
\hline 3. & Oilseeds & 11 \\
\hline 4. & Pulses & 6.5 \\
\hline
\end{tabular}

(Source: Praveen kumar and M.S. Nain, 2013) 
Table.2 Average Size of holding (acre per person) in India

\begin{tabular}{|c|c|c|}
\hline S. No & Year & Size of Holding (acre per person) \\
\hline 1. & 1970 & 0.94 \\
\hline 2. & 2000 & 0.56 \\
\hline 3. & 2050 (Projected) & 0.15 \\
\hline
\end{tabular}

(Praveen kumar and M.S. Nain, 2013)

Table.3 Declining percentage of cultivators in India

\begin{tabular}{|c|c|c|}
\hline S. No & Year & No of cultivators.(Millions) \\
\hline 1. & 1991 & 110.7 \\
\hline 2. & 2001 & 103.6 \\
\hline 3. & 2011 & 95.8 \\
\hline
\end{tabular}

(The Hindu, May 2, 2013)

Table.4 Level of value addition and processing of agricultural produce in India

\begin{tabular}{|c|c|c|}
\hline S. No & Item & Level of processing \\
\hline 1. & Fruits and vegetables & $2 \%$ \\
\hline 2. & Milk & $35 \%$ \\
\hline 3. & Poultry & $8 \%$ \\
\hline 4. & Marine products & $6 \%$ \\
\hline 5. & Meat & $21 \%$ \\
\hline
\end{tabular}

(Source: Assocham, 2014)

Table.5 Migration of people from rural to urban areas in India

\begin{tabular}{|c|c|c|c|c|c|}
\hline S. No & Area & 2001 & $\%$ & 2011 & $\%$ \\
\hline 1. & India & 102.9 & - & 121.0 & - \\
\hline 2. & Rural & 74.3 & 72.2 & 83.3 & 68.84 \\
\hline 3. & Urban & 28.6 & 27.79 & 37.7 & 31.15 \\
\hline
\end{tabular}

(Source: census 2011)

\section{Types of Enterprises}

According to N.G. Hegde (2005), while promoting entrepreneurship, we may consider different types of enterprises in agri-business.

\section{Farm Level Producers}

At the individual family level, each family is to be treated as an enterprise, to optimise the production by making best use of the technology, resources and demand in the market.

\section{Service Providers}

For optimising agriculture by every family enterprise, there are different types of services required at the village level. These include the input procurement and distribution, hiring of implements and equipment like tractors, seed drills, sprayers, harvesters, threshers, dryers 
and technical services such as installation of irrigation facilities, weed control, plant protection, harvesting, threshing, transportation, storage, etc. Similar opportunities exist in the livestock husbandry sector for providing breeding, vaccination, disease diagnostic and treatment services, apart from distribution of cattle feed, mineral mixture, forage seeds, etc.

\section{Input Producers}

There are many prosperous enterprises, which require critical inputs. Some such inputs which can be produced by the local entrepreneurs at the village level are biofertilizers, biopesticides, vermicompost, soil amendments, plants of different species of fruits, vegetables, ornamentals, root media for raising plants in pots, agricultural tools, irrigation accessories, production of cattle feed concentrate, mineral mixture and complete feed. There are good opportunities to support sericulture, fishery and poultry as well, through promotion of critical service facilities in rural areas.

\section{Processing and Marketing of Farm Produce}

Efficient management of post-production operations requires higher scale of technology as well as investment. Such enterprises can be handled by People's organisations, either in the form of cooperatives, service societies or joint stock companies. The most successful examples are the sugar cooperatives, dairy cooperatives and fruit growers' cooperatives in many States. However, the success of such ventures is solely dependent on the integrity and competence of the leaders involved. Such ventures need good professional support for managing the activities as a competitive business and to compete well with other players in the market, particularly the retail traders and middlemen.

\section{Areas of Entrepreneurship development in agriculture}

According to Bairwa and et al., (2014) the possible areas of entrepreneurship are:

Agro produce processing units: Dhal mills, Rice mills, decorticating mills etc.

Agro produce manufacturing units: Sugar factories, bakeries, straw board units etc.

Agro-input manufacturing units: Fertilizer production units, Bio fertilizers, agricultural implements etc.

Agro service centres: Input dealers

Miscellaneous areas: vermin-compost units, vegetable and fruits retail outlet etc.

\section{Strategies for promotion of agriprenuership}

\section{Entrepreneurship Facilitation}

Entrepreneurial facilitation is the process of providing direct, customized one-on-one assistance to an aspiring or active entrepreneur. Agriprenuers needs are recurrent and divergent, which can be greatly addressed by continuous entrepreneurship facilitation.

As farmers require different kinds of facilitations such as knowledge facilitation, input facilitation, technology facilitation, storage facilitation, marketing facilitation to carry out agriprenurial activities. Merely technical assistance by the extension professionals will not serve any purpose in nurturing agriprenuers.

Facilitation on various inputs and building networks enhances the chances of agro-based enterprises. 


\section{Mentoring/entrepreneurship coaching}

Mentoring /Entrepreneurial coaching is a process of creating business stimulation platform which will sharpen business acumen among farmers. There is a massive need to change and direct the way of thinking of farmers to transform them to agriprenuers through various extension activities.

\section{Building an entrepreneurial culture}

Encouraging entrepreneurial culture (a shared set of attitudes and competencies and abilities in managing farming enterprise) through capacity building and extension facilitation is a precondition for agriprenuership promotion. Agriculture is a potential sector for employment generation for vast majority of the population. Agriculture in Indian context is still considered as a family tradition and way of life and majority of the farmers continue to practice what their forefathers did or their neighbours do. So agriculture sector is facing various challenges like low Productivity, shrinking landholding, declining interest in agriculture, low level of value addition and processing, Lack of entrepreneurial abilities among farmers and Migration from rural to urban areas. But agriculture sector is witnessing radical changes at global level. In this context promotion of entrepreneurship is the need of the hour to address various challenges in agriculture and make agriculture highly attractive and profitable. Hence, sincere efforts need to made by various development departments for providing entrepreneurship facilitation, mentoring agriprenuers and creating entrepreneurial culture for promotion of agriprenuership development.

\section{References}

Bairawa S.L et al., 2014. International Journal of Scientific and Research
Publication; Vol 44, Issue 3, March 2014, ISSN 2250-3153, pp 1-5.

Business line; The Hindu; March 3, 2012; '12th Plan will see shift from primary to secondary agriculture'.

Hegde. N.G; 2005; 'Entrepreneurs Experiences in Agriculture', Presented at 'The VII Agricultural Science Congress at the College of Agriculture', Pune, February 16-18.

Indian Agriculture: Performance and Challenges

pib.nic.in/archieve/others/2012/mar/d20 12031302.pdf

Mittal; 2009; 'Entreprenuership Development through agriprenuerhip in India:

Crossing boundaries with Agri-export Zones (AEZ) '. A paper presented at ICARD at BHU,Varanasi.

Nagalakshmi. T and Sudhakar; 2013; 'A Agri-Preneurs: A Case Study of Dharmapuri Farmers', International Journal of Science and Research (IJSR), India Online ISSN: 2319- 7064, vol 2, issue 8, pp:208-214

Policy paper on 'Agriculture - Industry interface, value added farm products' naasindia.org/Policy\%20Papers/pp16.pd f (NSS 66th Round).

Praveen kumar and M.S. Nain; 2013; 'Agriculture in India: A SWOT analysis', Indian Journal of Applied of Research, pp: 4-6

Profit.ndtv.com/topic/value-addition-inagricultural-products-in-india.

Sengupta, Somini 2008; 'The Food Chain in Fertile India, Growth Outstrips Agriculture'. New York Times; Retrieved 23 April 2010.

Singh, Amarendra Pratap; 2013; 'Factors Influencing Entrepreneurship among Farming Community in Uttar pradesh'. Indian Journal of Commerce \& Management Studies. Sep 2013, Vol. 4, Issue 3, p14-19. 
Tiwari R.R., 2012; 'Wastage in fruits and vegetables', Economic times, May 4, 2012.

Tripathi and Agarwal; 2012; 'Rural development through Agripreneurship: A study of farmers in Uttar Pradesh'
Vol-2, Issue-2 ISSN: 2394-5788 PP. 534-542.

www.assocham.org

www.baif.org.in.

www.censusindia.gov.in

\section{How to cite this article:}

Padma Veni, C. and Bhagya Lakshmi, K. 2018. Need for Promotion of Agriprenuership to Address the Challenges in Indian Agriculture: A Critical Review. Int.J.Curr.Microbiol.App.Sci. 7(10): 2565-2572. doi: https://doi.org/10.20546/ijcmas.2018.710.298 